\title{
The Voluntary Precariat in the Value Chain: The Hidden Patterns of Home-Based Garment Production in Turkey
}

\begin{abstract}
This article explores the organisational characteristics and distinctive settings of the labour process of home-based garment work in the context of embedded control and consent relations in local garment productions in Turkey. Using Turkey as the case example of a garment export country in the global economy, the article explores the nature and organisation of home-based piecework at the micro level within a broader global garment production chains perspective. Conducted in two Turkish cities the study analyses the different cultural backgrounds of female workers and two distinct types of work, namely hand stitching and machine sewing of garments. The findings highlight the relationship between the cultural backgrounds of workers and the different types of work they undertake with control and consent practices as well as the patriarchal societal structure and relations in the context of local labour control regimes. Keywords: global value chains (GVCs), gender, garment industry, home-based work.
\end{abstract}




\section{Introduction}

The reorganisation of global production systems is influencing the changing division of labour between countries on different development paths. The ease with which production can be relocated and deindustrialization processes in advanced economies make workers in developing countries more vulnerable to exploitation (Thornley et.al., 2010). This means that workers need to meet the production requirements of a segmented and unregulated global production system while work is in itself becoming more precarious at the same time (Hattatoglu and Tate, 2016).

The precarious nature of working in the global economy is particularly obvious in the case of the global clothing industry. Large, international retail companies lead the globalisation of the clothing industry. The global clothing industry is one of the biggest connection points for workers from agriculture to manufacturing and retail across the world. While garments increasingly tend to be produced through global value chains (GVCs), power relations in the chain are often shaped by global brands that are in charge of research and development, designing, marketing and branding of products and services (Barrientos et al. 2010; Coe and Hess, 2013; Fernandez-Stark et al., 2011). Despite inherent challenges in estimating informal employment relations, there are approximately 75 million garment workers in the world today, $80 \%$ of which are female (Fashion United, 2016; Clean Clothes Campaign, 2013).

The nature of women's employment in the industry is frequently characterized by temporary contracts, occupational health and safety risks, long working hours and violations of workers' rights. This has often been described as a 'precarity'. However, it would be an oversimplification to describe the position of female workers in the global garment industry as their being part of an international 'precariat'. Instead, we 
suggest that a deeper understanding and explanation of power relations and women's (dis)empowerment must be understood from the perspective of different countries.

Turkey plays an important role in GVCs. In the early 1980s, Turkey's growth strategy shifted from import substitution to export orientation. At present, Turkey is a key supplier of garments to the EU. Its success can be attributed to its geographical proximity to the EU, along with low labour costs, which are often associated with the poor implementation of labour standards. In 2015, approximately $59.4 \%$ of the textile and clothing articles went to EU countries in the garment value chain, with the rest of production being divided between Central Asia, the Middle East, North Africa and the United States (European Commission, 2016; World Integrated Trade Solution, 2015).

Global garment production chains create a high demand for women's informal work, which takes different forms such as atelier work and home-based piecework in different regions across the country (Dedeoglu, 2012). Yet, according to the official statistics (TURKSTAT, Labour Force Statistics, 2016), the number of female workers in Turkey is substantially declining.

Although they remain largely invisible, female home-based workers in the garment industry are engaged in many parts of the industry and represent a significant share of urban employment in countries such as India, Thailand and Pakistan (Chen, 2014:1; Delaney et al. 2015). In these countries, women's work contributes to the global economy but is invisible to local labour market regulations and, in some cases, they may not even be identified as workers (Burchielli et al., 2014). As we will demonstrate in this article, Turkey might easily be included amongst these examples with its informal home-based workforce and unregulated work conditions.

This study focuses on the organisation of work in home-based garment production at the micro level (Taylor, 2010). It analyses the control mechanisms in the 
labour processes that are embedded in local social relations and argues that labour control is secured by providing female workers with the consent to engage in this type of work within a broader set of patriarchal relations and associated gender roles. The process of gender construction that is learned through family and society essentially shapes the obedience of women workers within the industry and their acceptance of its relatively poor working conditions (Ergun, 2004).

There are several academic studies on home-based piecework and the insecure conditions of the workers (Balaban and Sarioglu, 2008; Dedeoglu, 2011; Dedeoglu, 2012), However, the organisational characteristics of this type of work, the production process, local labour control practices and their gendered nature are still worthy of attention in GVC research. Precarious working conditions in the Turkish case have also received insufficient attention in the literature of home-based work, although Turkey constitutes a key producer country in the global garment industry. The objectives of the study are therefore: (1) to discover the nature of home-based garment work at the micro level with a broader global garment value chain perspective in relation to a gendered global production network (GPN) approach, and (2) to identify local labour control strategies that are embedded in patriarchal gender relations in Turkey. Our main assumption is that patriarchal social relations are hidden at the point of home-based garment production, and they shape the labour control patterns and consent, while minimizing resistance practices.

A qualitative research strategy was adopted. Semi-structured, and unstructured interviews were used as the main methods of empirical data collection. ${ }^{1}$ The fieldwork was conducted in the Turkish cities of Bursa and Tekirdağ in July and August 2015 -

\footnotetext{
${ }^{1}$ Semi-structured interviews were conducted with women workers and mediators, unstructured interviews were with chamber and organisation members who have information about the organisation and distribution of piecework.
} 
both constituting key examples of global garment production in Turkey - with a total of nineteen face-to-face interviews. Thirteen of the interviewees (nine from Bursa, four from Tekirdag) were women who work at home and participate in global garment production through piece-rated work, two were mediators (one from Bursa, one from Tekirdag) who organise and deliver the work to the women, and four were people from NGOs and chambers (Chamber of Commerce and Industry, Women Entrepreneurs Committee and Women Assembly of Tekirdag), who generally have access to the mediators or know the women's activities.

The interview questions probed the reasons and conditions of work at home; their profile as workers; relations with the mediators; their working conditions; the nature of the labour process; their desire to organize collectively; their changing role in the household and their connection to other women. Interviews lasted 0,5 - 1,5 hours, and all were audio recorded and later transcribed. The researcher also used fieldwork notes as a means of collecting data.

The author, as a woman, experienced no problems interviewing women in their homes in Bursa ${ }^{2}$. Interviews were conducted after accessing the female mediator in Bursa and piecework shop owner who works as a mediator in Tekirdag. It must be noted that it was almost impossible to find and access the women without mediators, as these women only interact with their mediator(s). In Bursa, after interviewing the women who live very close to the mediator, the researcher visited other women who work for the same mediator. These women had converted one room of their house as an atelier and worked with sewing machines.

\footnotetext{
2 Because of the conservative structure in these cities, it is potentially problematic to interview the women in their own houses.
} 
In Tekirdag, accessing the mediator was not as easy as was in Bursa. The author first found the women who sold their own products in the street market. Even though they were not interviewed because of their loose relations with the production network for national and international markets, they directed the researcher to a piecework shop. This shop is an informal workplace that distributes the work to the women, collects completed items when finished. It occupies an important component in the organisation of the work. Observing the labour process and interviewing the women in the shop in Tekirdag provided an opportunity to understand the network and labour control practices as a whole.

This article is structured as follows. In Section 2, the theoretical argument is developed adopting a developing country perspective. Additionally, the section aims to theoretically connect global garment production and local labour control practices with gendered employment relations and constraints on labour agency. Section 3 analyzes home-based work practices in the Turkish context after explaining the situation of female workers and the reasons for their limited participation in the labour market. Section 4 presents the findings of the study. Finally, Section 5 concludes the article.

\section{Precarious Work in the Global Economy - Theoretical Considerations}

The global economic crisis has had a determining effect on the historically disadvantaged position of women who are underrepresented in formal sector work and overrepresented in informal and vulnerable forms of employment. In developing countries, working women are typically in insecure, export-driven manufacturing sectors such as stitching garments and weaving textiles (ITUC, 2011; Chen, 2014). There are 'hidden costs' for women who are working in these labour-intensive sectors due to their precarious work conditions. For the most part, costs are 'hidden', because 
they are missing from official statistics. 'Women workers effectively provide a subsidy to production under supply chains and pay the price of government strategies that rely on precarious jobs' (Kidder and Raworth 2004: 13).

Standing (2011) views female workers as one of the most affected worker groups by precariatisation and stresses that the 'feminisation of labour' trend is a result of the expansion of the service sector. As a global trend, the decrease in household income because of the economic crisis has caused increasing participation levels of female workers in the labour market.

Precarity is a highly controversial term used for the analysis of recent global labour market tendencies that are characterized by inequalities and informality. The term has moved from being of marginal importance to a much more debated phenomenon within political and theoretical arenas (Shukaitis, 2013). Some of the debates relate to 'precarity' as a homogenous phenomenon that is explained from a Eurocentric perspective; i.e. it is a term that is used to describe job security based on the understanding of academics from advanced countries (Kalleberg, 2000; Burgess and Campbell, 1998; Heery and Salmon, 2002). Therefore, it has been argued that it may not be possible to apply the concept in the same way as different countries proceed on their own unique development paths (Senses, 2015). From this point of view, discussions about precariousness widely give explanations for the 'West' rather than the 'Rest' (Breman, 2013). In fact, precariousness might be seen as a natural condition for the workers and urban poor in developing countries (Munck, 2013). Hence, precarity is the norm for this part of the world in the history of capitalism (Neilson and Rossiter, 2008). Thinking about the applicability of precarity in the North-South (or West-Rest) context from this perspective, it is neither possible to place Turkey on a northern Fordist type development path, nor on a Southern kind of market economy, 
but in a category between (Senses, 2015); and it is better to think about the concept with its own demonstrable position.

As mentioned, precarious working conditions in the Turkish context need to be addressed, in particular, from the perspective of informal work for women. However, as the focus of this article is informal home-based garment work, it is better to focus on the specific prospects of this type of work in the Turkish case after placing the concept in the GVC/production network framework.

\subsection{Between Precarity and Invisibility in the Production Chain: Making Female Labour}

\section{Visible}

In order to understand the prerequisites of home-based work relations, it is necessary to comprehend the relations between this specific work type and the politicaleconomic contexts of the global relocation of production relations at the macro level (Taylor, 2010). There is no doubt that the motivation behind the movement of production to developing countries is not only the cheap labour force, but also the local work and employment relation systems for overcoming the indeterminacy of labour. From the theoretical standpoint of labour process analysis, a tension exists in capitalist production between the need for labour control to resolve this indeterminacy and the need for the creative and efficient participation of workers. Labour control practices evolved with historical phases in the development of the labour process (Jonas, 1996; Edwards, 1979; Burawoy, 1979) and early labour control practices often focused on advanced economies. However, as previously mentioned, when global production moved low wage production segments of the value chain (Anner, 2015), it became important to evaluate labour control regimes in accordance with the movements of capital. 
The GVC framework adopts a broad picture of power relations and asymmetries at the meso level in the context of global production activities. Although labour and labour studies perhaps feature less prominently in the GVC literature (Riisgard and Hammer, 2011), more recent studies aim to 'put labour in its place' and explore the interrelationship between labour process and GVCs (Newsome et al. 2015; Coe and Hess, 2013). Additionally, with the GPN approach, more attention was given to the importance of labour in a larger analytic picture and analysing the dialectics of globallocal relations became more achievable. However, there are still limitations of GPN approach when it comes to labour (Rainnie et al. 2011) which is embedded in the specific social relations of the labour process. Therefore, the Turkish case is important in exemplifying how value is created by workers and how power dynamics are maintained (Taylor, 2010) through gendered employment relations within the labour process in a garment supplier country, where workers' associational power is very weak and resistance is limited against 'reframed' control regimes (Jenkins and Blyton, 2017).

Riisgard and Hammer (2011) emphasize the embedded nature of labour, and they relate the notion of local labour control regimes to the GVC framework. Local labour regimes are defined by Jonas (1996) as 'historically contingent and territorially embedded sets of mechanisms'. They discuss the local and institutional embeddedness of labour agency and identify the embedded nature of social relations of production. The relocation and outsourcing of production was based on the exploitation of local labour control regimes (Riisgard and Hammer, 2011). The local and indirect methods of labour control were practiced on relations in workplaces and in the family sphere with paternalistic models of control and consent (Jonas, 1996). In the Turkish case, these paternalistic models are clearly observed and constitute the distinguishing 
characteristic of the employment relationship in home-based garment production at the micro level (Taylor, 2010).

As mentioned, the GPN literature developed a relational framework, which surpassed the more narrow focus of GVC analysis (Delaney et al. 2015) and recent studies also concentrate on labour agency in GPNs (Carswell and De Neve, 2012; Pattenden, 2016; Coe and Hess, 2013; Cumbers, 2015; Newsome et al. 2015). Coe and Hess (2013) emphasize the importance of 'putting workers on the map'. Carswell and De Neve (2012) contribute to GPN analysis with a horizontal approach - to complement the vertical and linear analysis of networks - that explores the role of local and social relations in shaping labour agency. Rainnie et al (2011: 160) also suggest 'a strategy for more fully incorporating labour into GPN analysis, focusing upon how workers in GPNs are active shapers of such networks'. Nevertheless, home-based garment production networks in Turkey place significant constraints on the labour agency potential of women workers as active shapers of the production networks. The different dynamics affecting the agency of workers will be clarified in the following sections.

In this perspective, in relation to GPN approach, gender relations are a crucial component of global production and reproduction relations, and these relations are embedded in particular national and local cultures that shape the connections between the production processes and the organisation of labour (Dedeoglu, 2012: 15; Carswell and De Neve, 2013). The garment industry is one of the largest export industries and constitutes one of the main industries - second after unpaid family work in agriculture - where women informally work in most of the developing countries in the global production system. Particularly in big cities economic inadequacies and high unemployment rates make it a compulsion for some women to find work, especially the ones who have migrated from rural areas. 
The occupation of a garment worker is defined as a low-paid, low skilled and a replaceable source of labour in the global production system; they are largely invisible within the supply chains (Jenkins, 2013). Female garment workers are surrounded by social relations and reproductive activities, which shape their potential for labour agency; and their agency is structured by wider social norms and gender relations as well as their domestic responsibilities (Carswell and De Neve, 2012). In the Turkish case, home-based women workers' potential as an agent is weak and limited because of local control practices and their obedient and coherent gender roles.

\section{Home-Based Garment Work and Its Distinctive Characteristics in Turkey}

Home-based pieceworker women in garment production are expanding as a form of precarious work; they work in their homes and are seen as housewives who 'voluntarily' work for additional money in their spare time rather than as workers (Hattatoglu and Tate, 2016: 97).

Women have been a part of the home-based production system, especially for producing use value, even before the factory production, and home-based work predates the industrial revolution (Hattatoglu and Tate, 2016:96). However, since the production system has shifted from big factories to disparate small-scale workplaces again, and with the increasing importance of informal economic activities, the home became an important workplace. The 'rebirth' of home-based work was the result of this shift, and industrial production at home has become the focus for understanding the structure of garment value chains (Balaban and Sarioglu, 2008). Women have a crucial role in the labour process of producing change value in the garment industry (Atılgan, 2007). 
In Turkey, one of the main reasons for the decline of the female labour force is the stagnation that took place in the manufacturing sector at the end of the 1980s. The rise of unemployment rates generally affected women workers in this sector. In addition, subcontracting in the manufacturing sector increased because of high labour costs, and home-based working practices became the widespread tendency for 'unskilled' women (Ecevit, 1990).

The percentage of women in the labour force was $31 \%^{3}$ in early 2016 , compared to $62.8 \%$ in OECD countries and $66 \%$ in EU countries. The percentage of home-based workers is $2 \%$ of the total women employment rate (Toksoz et al., 2014) and this includes piece-rate garment, textile workers and workers employed in care services at others' homes and domestic workers. However, the actual percentage is higher as most of the informal home-based workers are not included in official statistics, because they define themselves as housewives during the data collection periods. These women constitute $55.4 \%$ of the population not in the labour force (TURKSTAT, Labour Force Statistics, 2016). The informalisation of female labour deepens with the hidden reserve of home-based workers and unpaid women who consider their work as an extension of their domestic obligations and roles, and home-based work may not produce conflicts with women's family duties (Kidder and Raworth, 2004). In other words, insecure work is legitimised by gender ideology and, as a result of multiple power relations, local subcontractors and mediators benefit from women's work at home (Ergun, 2004).

The determinants and barriers for women to join formal labour markets are generally divided into two. The first group of barriers is related to labour supply, including issues such as patriarchal culture, marital status, inadequate child care

\footnotetext{
${ }^{3}$ While $65 \%$ of the total female employment are working as regular employees, $24.4 \%$ of the women workers still work as unpaid family workers. The sectoral division of female employment is $26 \%$ agriculture, 15.9\% manufacture and 57.2\% service (Turkstat, Labour Force Statistics, January 2016).
} 
services or lack of education, and the second group is related to low labour demand (Toksöz et.al, 2014; Ilkkaracan, 2012).

The male breadwinner model and 'patriarchal contract' are the determining factors of the gendered division of labour and institutionalized gender roles establish constraints on women's labour supply in Turkey. Especially during the import substitution industrialisation period (1950-1980), Turkey's growth process was shaped predominantly by male labour. The general view of women was 'housewification' , and women of rural origin were happy to become the mistress of their own houses ${ }^{4}$. Even though there has been a relative feminization of the urban labour market in the exportled industrialisation period after 1980, female labour force participation was still very low (Ilkkaracan, 2012).

It is essential to indicate here that well-educated and skilled women do take their place in the formal sector; women who have a higher education degree constitute $71.5 \%$ and those with a vocational high school degree constitute $40.5 \%$ of the female labour force participation rate (TURKSTAT Labour Force Statistics, 2016). The economic activities in Turkey of low educated and unqualified women concentrate on informal and marginal work such as home-based work and care work; since the 2000s, female employment is an important source for informal economy labour in big cities. There are three types of informal work for women in Turkey; industrial home-based work, unpaid self-employed work for their own company, and home-based care work (Toksöz et al., 2014).

The low socio-economic status of women in value chain settings reinforced their pre-existing situation as a cheap source of labour, and they became the workforce

\footnotetext{
${ }^{4}$ Additionally, according to the IEMS (Informal Economy Monitoring Study) sector report on homebased workers, home-based work is valuable for women; they have the ability to combine their gender roles and unpaid work, and have a flexible work schedule (Chen, 2014: 2).
} 
of choice in many labour-intensive operations (Jenkins, 2015: 200). After Turkey's adoption of export-oriented industrialisation in the 1980s, enterprises in the garment industry developed cost-cutting strategies for maintaining their competitiveness in the global market, and subcontracting became a common way to reduce labour costs. Home-based piecework was an integral part of these subcontracting relations (Sarioglu, 2013: 482).

It is also important to mention the special geographic location of Turkey that makes its situation more important in the supply chains. The Turkish garment sector has a global connection through transitional markets in Eastern Europe, Russia and Europe (Dedeoglu, 2012). In this context, women join the disadvantaged worker groups in the labour markets for various reasons and become the most preferential labour category due to their disposable nature. ${ }^{5}$ They are also preferred by global and local employers because of their specific situation as a form of labour that is less likely to organise and resist against working conditions and long working hours because of their weak structural and associational power (Ergun, 2004; Hattatoglu and Tate, 2016; Dedeoglu, 2012).

Home-based work constitutes an informal relationship of employment (Balaban and Sarioglu, 2008) and home becomes a location that enables the spatial meeting of family and production relations. Working at home has a contradictory effect on women's social status; it makes their life easier as their work is at home, but simultaneously has a negative effect as home makes them dependent on the traditional roles such as child and elderly care and everyday household tasks ${ }^{6}$ (Aktas, 2013).

\footnotetext{
${ }^{5}$ Especially migrant women who are not able to join the formal labour markets because of their lack of education, having children at home and strict patriarchal control, engage in industrial home-based work in Turkey (Cinar 1994; Toksoz, 2014; Dedeoglu, 2012).

${ }^{6}$ Home-based women employment constitutes a dual situation in big cities; working in the informal sector gives women an employee status as paid labour, which is a modern relation between employee and employer. On the other hand, working conditions are based on paternalistic and patriarchal societal
} 
The gender division of labour is inherent in the organisation of home-based work. In this sense, it is very important to understand the dynamics of the organisation of home-based garment work in the value chains. Control practices in particular are shaped by the varied patterns of gendered organisation of work and labour process (Sarioglu, 2013). Women workers are dependent mediators for the supply of the work and raw materials. They also have no control over the means of the production (Balaban and Sarioglu, 2008). It is the gendered control mechanisms that make the women's obedience easy and implicit, and resistance unnecessary, as they see their relations with the mediator as part of the patriarchal consensus.

Home-based work takes on three different forms in Turkey; piece rate work $^{7}$ (for an employer, subcontractor or mediator), order-based work and own account work. The first two types, which constitute the samples of this study, are dependent on an employer or mediator, whereas the last one is independent work and has the lowest income (Coskun, 2010).

Piece rate home-based work is an integral part of industrial subcontracting relations in Turkey. Sending parts of production - most of the time stitching an item on a garment, or in some cases sewing some parts of the garment with the sewing machine - to home-based women enables companies to save on labour costs and costs for space, machinery, electricity, and other required inputs such as health and safety expenses (Sarioglu, 2013).

The home-based piecework labour process may be summarised by long and uncertain working hours, unclear employment conditions with mostly no contract,

codes, therefore traditional and modern working relations appear together in the nature of work (Kalaycioglu and Rittsberger, 1998).

7 The author uses the home-based piece worker as a worker who works for a subcontractor/mediator where there is a global chain of garment production; see also Hattatoglu and Tate, 2016. 
monotonous and repetitive working conditions, self-defined labour time with strict deadlines, and, because the work requires hand skills, it is defined as unskilled work in the labour markets.

Home-based workers complain about the cumulative negative effects of physical effort, long hours, stress and frustration. In some cases, there are also risks at home when it comes to maintaining the occupational health and safety of both women and children. For instance, women sometimes buy raw thread for sewing and colour it themselves for economic inabilities, which is a chemical process. The dyeing of the thread can cause breathing problems. Additionally, sewing machines, scissors and needles pose clear risks for children at home (Aktas, 2013). However, there has been almost no studies about these risks and, as they are invisible in the social security system, they use the health insurance of their father or husband (if they have one) in the case of disease or accident (Dedeoglu, 2012; Aktas, 2013).

The global production system not only creates a precarious employment situation but also generates the conditions of new forms of organisations for those not included in traditional trade unions (Hattatoglu and Tate, 2016, Tartanoglu, 2015). Even so, most of the home-based workers cannot express their voice or bargain for better conditions, and they have limited scope for negotiation due to unequal or exploitative value chain dynamics (Chen, 2014). They partially organise worldwide under several solidarity organisations and associations such as HomeNet (Network of Homebased Workers Worldwide), WIEGO (Women in Informal Employment: Globalising and Organising), the Federation of HomeWorkers Worldwide and Homeworkers Worldwide. However, women workers' invisibility and various other social norms and values constitute the main barriers for women to act collectively (Delaney et al. 2015). 
The representation of home-based workers is slightly different in the Turkish case due to the cultural reasons. Home-based work constitutes a typical informal, disadvantaged and precarious employment form, but home-based women workers have more voice, especially in the household against the male members of the family, and in some cases working has a positive effect on their empowerment. However, this is not enough to extend the control relations that are embedded in gender roles and power hierarchies. Additionally, trade unions pay inadequate attention to home-based workers in Turkey. Even so, home-based women workers organised to develop solidarity as cooperatives in the 2000s. The main motivations of these cooperatives were higher wages and the elimination of the work of the mediators or subcontractors. The common characteristic of these was their income-generating organisation status. Furthermore, the first rights-based organisation of home-based workers was founded in solidarity with HomeNet, as Turkey HomeNet in 2007, and the Union of Home-based Workers (Ev-Ek-Sen) was launched two years later as a worker organisation organised by female workers themselves. Their primary struggle is for visibility and recognition. However, according to the existing trade union regulation, home-based workers are not able to form or join a union because they are not formal sector workers, and they have no social security number. Instead they rely upon the international legislation and the Turkish government has started a legal case to shut the trade union down (Hattatoglu and Tate, 2016). The trade union still continues its struggle for visibility and organises women for solidarity.

As pointed out in their declaration (Ev-Ek-Sen, 2009); 'We, home-based workers, are among the most invisible sections of precarious workers, so that there are even times we find it difficult to explain that we also work, that we are also workers like other workers', the main problem of unionization is the situation of the women as 
informal workers and their weak potential for labour agency. In the meantime, the activities of the union are directed by experienced workers who are politically active and by academics from the field of work and employment relations. Therefore, the effectiveness of the union is problematic from the founding stage and its sustainability is controversial since it does not have the widespread support of the workers. Women's consent to their working conditions and their relations with the mediators and the employers as an extension of their family interactions make resistance or collective actions unnecessary, and, in these circumstances, their work appears as voluntary participation.

These relations and gendered labour control mechanisms will be discussed in the following findings section in greater detail.

\section{Research Findings}

\subsection{Profile of the Women}

The characteristics of the women who participated in the research differ predominantly according to the place of birth. Five of thirteen interviewees were born in Bulgaria and their education level was higher than the women who were born in Turkey. They finished high school in Bulgaria; working and contributing to the family income was of importance to them. They all mentioned the importance and positive meaning of 'working' outside of the home in Bulgaria. One of them explained what working means for these women:

'Work makes someone "human". You are something when you produce. It is so special when you go to market with the money you have earned, with your own money' (Machine and handworker, Bursa, 46).

The women who were born in Bulgaria had to move to Turkey in the 90s following the compulsory immigration of Turks that began in 1989. Most of the 
immigrants have settled in Bursa and Istanbul and experienced difficulties initially finding a job. Women of the families had major responsibilities to earn money and provide a decent lifestyle for their children during this period. Most of them were educated technically (four years in technical high schools) to work in the garment sector, therefore it was possible to find a job in a textile factory or garment atelier. The mediator interviewed in Bursa also worked for ateliers and factories during her first years in Turkey.

'As we came from a communist country, we looked for a secure job at the beginning. We did not want to work at an outsourced shop without social security. I knew all the machines for textiles and sewing. I was more qualified than the others. I could do everything.' (Machine worker and mediator, Bursa, 51).

However, the women who were born in Turkey, especially local women in Bursa, had a lower education level; they generally left the education system after primary school. It is easy to observe the effect of patriarchal family structures on these women; traditional gender roles make it difficult to work outside:

'My husband did not let me work. "Working" was not common here before Bulgarians arrived anyway. I wanted to work in a factory, maybe in a trustworthy one. My husband said his social security is enough for both of us, "stay at home"”. (Handworker, Bursa, 53)

The women who participated in the research were aged between 20 and 53 years old, all were married with one, two or three children. Women's work preferences in this case change with their life situation, similar to the other studies (Carswell and De Neve, 2013). Although the importance of working or earning money varies according to the place of birth, age, education level or type of work, one role is the most important for all of them, which forced or obliged them to work at home: motherhood. As women's identities, as workers, are shaped around their gender roles, this identity never 
precludes motherhood or being a wife (Toksoz, 2014: 19). Even women who immigrated from Bulgaria and worked in a decent factory, after giving birth to their first child, stopped working and started to look after their children. This is also the case for local women; they can only do handwork or work with sewing machines in their atelier rooms if there is time after childcare activities. All women juggle their gender roles and piecework they try to finish.

'I have to work at home. First, I had children at school age and I had to take care of them as a mother. I couldn't leave them alone. Now, I can't work outside of the home because of my age'. (Machine worker, Bursa, 33)

'A mother should be at home in my opinion. You have to cook; you have to take care of your children. If you work outside of the home, all these tasks stay unfinished'. (Machine and handworker, Bursa, 46)

At this point, it is clear that all interviewees agreed on the idea that "women should work outside in a formal job". However, when the issue was that of being a mother and taking care of the children, staying at home and working there became an acceptable phenomenon by internalizing gender roles. In addition to the profile of the women, organisational aspects of home-based work and patriarchal relations in the control of labour are the issues that need to be explained in more detail in the current case.

\subsection{Types of Tasks, Organisation of Work, and Control Practices}

All of the interviewees were working without a contract and their working hours were highly irregular. The structure and nature of work observed in this study is parallel to the explanations and analysis of home-based work in the literature: 'It represents a low-paid and labour-intensive work form primarily conducted by married women, where the productive and reproductive activities of women are juxtaposed both spatially and practically" (Balaban and Sarioglu, 2008: 17). However, embedded 
control relations that vary according to the work types and means of production need to be emphasized more.

\subsubsection{Handwork}

The women workers who participated in this study had different tasks that they completed at home. Nine of thirteen interviewed women were applying handwork on finished garments, four of these nine were working for the piecework shop in Tekirdag and their tasks changed according to the work that the shop has at different times of the year. For instance, during the interviews, the mediator who owns the shop was working for a scarf factory in Istanbul. The main task of the shop was sewing and correcting the edges of the silk scarves, which requires gentle handwork as there is a possibility of damaging the fabric. The factory, a very well-known brand that exports its products to EU countries, delivers the silk fabric to the shop. The shop owner, the mediator, measures and gives the fabric to the women in metres. They generally decide how many pieces they can finish according to their other work at home. When they finish their task, they bring the work back and receive their money after the shop owner has carefully checked the quality. Before the delivery of every new product, the mediator provides the women with a short training at the shop. Thus, he is the only person who manages the process at this level. He works with some other informal workers who make the barcoding (stitching the brand), ironing and packaging at the end of the work which is done by women. The product is also checked for any defects during these processes, especially by the ironers. Finally, the mediator sends the product back to the factory. The factory has different teams and outsourced work relations, like the one in Tekirdag, in different cities. Work is mainly organized by the mediators, and they are responsible in the case of any defects on the scarves. Therefore, power relations are 
shaped by the structure of the value chain starting from the purchasing company in Europe to the mediators and to the women workers.

Most of the interviewed women did not have the knowledge about where the product goes or the rest of the production chain after they deliver it to the shop or to the mediator. The mediators are the only actors in the production network whom they have a connection with and this limited interaction intensifies their invisible position and low participation capacity in the network (Delanet et al. 2015). Additionally, both of the mediators who were interviewed also have limited information about the final destination of the product they work on:

'I do not know where these go abroad. We just deliver to the factory; I have no idea where the factory sends them. But I think they go to several countries abroad. I deliver 30 or 40 thousand scarves in winter. This is quite a big number. There are 8 teams like me in different cities. You can imagine how big the business is. So it is unlikely that this production is just for national markets'. (Mediator, Tekirdag)

Owning a piecework shop as an entrepreneurial activity requires neither initial capital nor raw materials. Mediators manage the flow of work between factories and houses and carry out specific phase of the production (Sarioglu, 2013: 486). Their main role in the labour process is to secure the labour consent via patriarchal relations. This is the main dynamic of the local labour control regime in the outsourced garment labour process.

At this point, it is essential to emphasize that home-based work does not take place under the strict surveillance of capitalist management. The nature of work also causes an isolation of workers from each other. Therefore, ensuring direct control in the workplace is difficult to ensure. In such a case, the locally shaped control relations characterize the organisation of the work, and, in order to understand the control mechanisms, thinking of the process with these dynamics in mind is a necessity 
(Balaban and Sarioglu, 2008). Women control their own work since they feel a responsibility due to their close relationship with the mediators. According to the observations at the shop during collecting and delivering the finished work, the relationship between the mediator man and women is based on trust, which is generally seen as a part of kinship relations; they see the mediator as a brother or a father. Their trust is based on a reflection of traditional family structure on the work relations (Dedeoglu, 2010). This situation also makes it easy to receive the consent and permission to work from their husbands. However, this type of workplace relationship hides both the exploitation and the subordination of female workers (Sarioglu, 2013: 481-493). One woman explained her relationship with the mediator as follows:

'I trust him [the mediator] so much. When you deliver the finished work, you can definitely get your money. If you need money that week and could not finish the work, he can pay you anyway. He says you can give the rest next week'. (Handworker, 36, Tekirdag)

The other five women also sewed embroidery on finished products or performed quality control of finished garments that come to the mediator from a textile factory in Bursa. This factory exports the products especially to East European countries and Russia.

Handworkers who stitch garments arrange their work according to their roles at home. Gender roles come first in their daily life, so they have a relative control on their labour process. These women did not complain about the bad conditions or difficulties of their work and talked about it as a 'handcraft' or free time activity:

'There is no disadvantage of working at home in my opinion. You can do both your housework and your handwork. First finish cooking, clean the house then come back to your handwork. You can arrange the time'. (Handworker, 36, Tekirdag) 


\subsubsection{Working with Sewing Machines}

The mediator in Bursa has owned several garment ateliers in previous years at different times. She gave 'work' to her neighbours and to women she knows from Bulgaria. These women lived in a different area of Bursa, known among the high immigrants. It was possible to hear a sewing machine from every house in this street. Three of the interviewees lived here and worked for the mediator and for other shops. A significant characteristic of their job was that they owned the machine and they produced some parts of the garment with a sewing machine, instead of working on a finished product.

Women who worked with sewing machines had to follow deadlines and arranged housework according to the piecework. The working conditions of these women were worse than that of the manual workers because of the strict deadlines for the export process, and they have more control over their work. Some of them cannot work outside because of the health problems they have from earlier years when they worked in factories.

'I have backaches all the time. I am gaining weight because of sitting all the time. I don't have any time for myself. I wish I could work until 6 and then have a rest. But after 6 I have to finish the housework'. (Machine worker, 33, Bursa).

Even though these women's working conditions are harder than that of handworkers, they still consent to the work organisation, as they think they do not have any other option but to work at home. Motherhood is still the main role and they internalize their gender roles as a mother and wife.

Interviewees were unable to figure out their exact monthly income because of the irregular work type, both handwork and working with sewing machines. Their income depends on how many pieces they manage to finish with the housework they have to do. However, it is possible to indicate that the women who work for the 
piecework shop in Tekirdag earn 1 TL per piece, and the women who work with sewing machines in Bursa earn between $10 \mathrm{kr}$ to $2 \mathrm{TL}^{8}$. Three of thirteen women have their own social security, because they had a formal job before they got married, eight women have not worked in a formal job outside of home in their entire life and are not covered by social security. They benefit from their husband's health insurance, if he has one. The following quote clearly explains the irregularity of piece-based income:

'I earn 10kr per piece, $100 \mathrm{TL}$ per 1000 pieces. I can finish maximum 60 pieces per day, if I work nonstop all day, and I earn not even 1 TL. I can finish 1000 pieces in 15 days. The work comes very irregularly, I cannot say every week or every month, whenever they [the mediator] gets the work, but I have to work in the end'. (Handworker, 49, Bursa) Most of the interviewees were not aware of their rights and had a lack of collective interest as they do not have a proper work experience. Because of their obedient position in the production network, their potential as an agency and associational power are highly limited. However, one of the women, who was born in Bulgaria and used to work in a factory, has mentioned the importance of the representation of collective interests with the following words:

'I used to be a trade union member. Turkey's biggest mistake is not giving enough importance to being organised and to collective actions, because we are a country of outsourcing and we do not have the right to get organised. Even the small fish move against the big fish together. Collective action is a necessity. Even formal workers do not have this right, so how can we get it?' (Machine and handworker, Bursa, 46)

After all these summarized circumstances, there is no doubt that that the conditions of women workers are precarious and insecure. Apart from the women who have social security, none of them have a hope for their future life:

\footnotetext{
81 Euro is approximately 4 TL.
} 
'I am fed up with this job. But we need it. I also work at nights just to keep to the deadlines. I am very negative about the future. I don't think I can see better days through the end of my life'. (Machine worker, 43, Bursa)

However, the discussion here is much more complicated than simply deciding whether to place them in precariat or define their working conditions as precarious. There is a need for further exploration to state home-based women workers' position in the global production network in a relation to the local social context.

\section{Conclusion}

This article considers home-based garment work practices and focuses on the working conditions and organisation of the work in the context of local labour control dynamics and workers' consent at the point of production. It contributes to the debates about the position of labour and labour process in GVC and in a broader context global production network (GPN) approaches from a developing country perspective. The main results of the study show that there are several points needing to be emphasized such as women's 'voluntary' approval of working at home because of their consent and internalising their traditional gender roles, as well as the differentiation of women's orientation to the work and their potential as an agency according to cultural background, education level and job profile.

There are several barriers to women's participation in the labour markets. Patriarchal dynamics are one of the main restrictions women face in joining formal employment. Working at home is an appropriate way for women not just to comply with the patriarchal relations but also to fulfil their gender roles. As they naturally internalize their gender roles, they do not embrace themselves as a worker and there is consent among women to the working conditions and gender division of labour in the organisation of work. In some cases, they consider working at home as an advantage 
by being close to their children. They accept the role of mediators as a part of patriarchal relations and build employment relations based on trust. Even in cases where the mediator is a woman who takes the piecework from another male mediator, there is still a tight control mechanism based on hierarchies between women. This network of women generates new forms of surveillance and authority relations between homebased garment workers and the female mediator (Dedeoglu, 2010). This makes the control process manageable although it is quite problematic due to the different locations of the workplaces.

While women consent to work at home, it is easy to define their work as voluntary participation. However, voluntary participation must be evaluated in the context of gender norms and it is difficult to draw a sharp line between voluntary and involuntary participation (Vosko et al. 2009), it is not easy to explain homeworker women's perceptions about their situation with individual choice.

Most of the interviewees in this study state their desire to work outside home, but their maternal roles is a restriction to participating in the formal labour markets. Even though there are available childcare services, they prefer to stay at home to be a good mother to their children. There is no difference between women considering the type of work, cultural background or means of production when the issue is 'motherhood'. From this point of view, they form the 'voluntary' precariat. Furthermore, these women do not define their job as work. Therefore, observing any creative responses or resistance to their precarious conditions is reasonably difficult. Even women who were interviewed informally and are head of the Women Entrepreneurs Committee and Women Assembly of Tekirdag approve home-based work and attribute a positive value to this type of work. They think home-based garment work is suitable for uneducated women and it plays an effective role in women's 
empowerment. In the end, home-based work stands between 'the women's contradictory roles as workers in the sphere of waged work and as mothers and housewives' (Sarığlu, 2013: 494).

The precarity of female workers varies according to the cultural background, education level and type of their tasks. Women who work with sewing machines have harder working conditions than women who do embroidery work, such as stitching garments or sewing manually. Excluding those who had social security, none of these women had hopes for their future life and they were unsatisfied with their wage and working conditions.

Apart from the worker perceptions, home-based garment work in Turkey constitutes an important link within the global garment production chain, which is shaped by the intersection of global labour demand and local supply (Dedeoglu, 2012). Even though workers do not see or recognize themselves as a part of this chain, they are the weakest link of the chain with low wages, long and irregular working hours or without any job security. Their invisible position in the GPNs is undoubtedly as a result of their few connections with the other actors such as brands, suppliers, trade unions or worker organisations and their weak associational power (Delaney et al. 2015). Especially in the Turkish case, developing agency among home-based women workers in order to make them more visible is difficult and restricted with "norms and values as well as gender and household relations' (Carswell and De Neve, 2013: 62).

The results of the research show similarities with the other studies (Hattatoglu and Tate 2016; Sarığlu 2013; Carswell and De Neve, 2013; Delaney et al. 2015) in order to explain the organisational aspects and labour process of home-based garment work that are basically shaped by patriarchal relations and broader structural factors. However, the contribution of this research is to state the specific aspects of the local 
labour control dynamics in the global garment value chain and women workers' consent to these hidden control relations in the case of Turkey. Additionally, contributing to the GVC analysis in relation to a gendered GPN approach to overcome their limitations, especially addressing informal and home-based labour, which is embodied in the networks, has a significant importance for the paper. Nevertheless, there is still need for further research to analyse the different dynamics and local work practices in various developing countries that affect the position of women workers in the global garment production networks.

\section{References}

Aktas G (2013) Üretiyorum Öyleyse Varim: Buldan'da Ev Eksenli Calisan Kadinlarin Aile ve Toplumsal Yasamda Gorunmeyen Emegi. Sosyal ve Beşeri Bilimler Dergisi 5 (1): $258-267$.

Anner M (2015) Social Downgrading and Worker Resistance in Apparel Global Value Chains. In Newsome K, Taylor P, Bair J and Rainnie A (eds), Putting the Labour in its Place- Labour Process Analysis and Global Value Chains. London: Palgrave, pp.152170.

Atılgan S (2007) Evden İçeri Bir Ev: Ev Eksenli Üretim ve Kadın Emeği. Birikim 217:134-140.

Balaban U and Sarıglu E (2008) Home-based Work in Istanbul: Varieties of Organization and Patriarchy. Available http://www.spf.boun.edu.tr/docs/HBW_in_Istanbul_Varieties_of_Organization_and_ Patriarchy.pdf (accessed 3.8.2014)

Barrientos S, Gereffi G and Rossi A (2010) Economic and Social Upgrading in Global Production Networks: Developing a Framework Analysis. Available at: http://www.capturingthegains.org/publications/workingpapers/wp_201003.htm (accessed 13.01.2016).

Breman J (2013) A bogus concept. New left review 84:130-138.

Burawoy M (1979) Manufacturing Consent. Chicago: University of Chicago Press. 
Burchielli R, Delaney A and Goren N (2014) Garment Homework in Argentina: Drawing Together the Threads of Informal and Precarious Work. The Economic and Labour Relations Review 25(1): 63-80.

Burgess J and Campbell I (1998) The Nature and Dimensions of Precarious Employment in Australia. Labour and Industry 8 (3): 5-21.

Carswell G and De Neve G (2013) Labouring For Global Markets: Conceptualising Labour Agency in Global Production Networks. Geoforum 44: 62-70/

Catalbas GK (2015) Kadinlarin Isgucune Katilimini Belirleyen Faktorlerin Belirlenmesi: Panel Veri Yaklasimi. Kafkas University Faculty of Economics and Administrative Science Journal 6 (10): 249-280.

Chen M (2014) Informal Economy Monitoring Study Sector Report: Home-Based Worker. Cambridge, MA, USA: WIEGO.

Clean Clothes Campaign (2013) Gender: Women Workers Mistreated. Available at: https://cleanclothes.org/issues/gender (accessed 11.5.2016).

Coe NM and Hess M (2013) Global Production Networks, Labour and Development. Geoforum 44: 4-9.

Coskun G (2010) Building Women Homebased Workers, Organizations in Turkey. Global Labour Journal Special Issue on Globalization (s) and Labour in China and India 1 (1): 212-216.

Cumbers A (2015) Understanding Labour's Agency Under Globalization: Embedding GPNs within an Open Political Economy. In Newsome K, Taylor P, Bair J and Rainnie A (eds.) Putting the Labour in its Place-Labour Process Analysis and Global Value Chains. London: Palgrave, pp. 135-152.

Dedeoglu S (2010) Visible Hands- Invisible Women: Garment Production in Turkey. Feminist Economics 16(4): 1-32.

Dedeoglu S (2011) Gendering Industrial Subcontacting Work: A Qualitative Study of Garment Ateliers in Istanbul. Asian Women 27(3): 27-53.

Dedeoglu S (2012) Women Workers in Turkey- Global Industrial Production in Istanbul. New York: I.B. Taurus. 
Delaney A, Burchielli R and Connor T (2015) Positioning Women Homeworkers in a Global Footwear Production Network: How can Homeworkers Improve Agency, Influence and Claim Rights? Journal OF Industrial Relations 57(4):641-659.

Ecevit Y (1990) Kentsel Uretim Surecinde Kadin Emeginin Konumu ve Degisen Bicimleri' in Kadin Bakis Acisindan 1980'ler Turkiyesinde Kadinlar. In Tekeli S (ed), Istanbul: Iletisim, pp.105-115.

Edwards R (1979) Contested Terrain: The Transformation of the Workplace in the Twentieth Century. New York: Basic Books.

Ergun E (2004) Atolye Kizlari (Workshop Girls)-A study of Women's Labour in the Export Oriented Garment Industry in Turkey. PhD Thesis, University of Newcastle Upon Tyne, UK.

European Commission (2016) European Union, Trade in goods with Turkey. Available at: http://trade.ec.europa.eu/doclib/docs/2006/september/tradoc_113456.pdf, (accessed 12.08.2016).

Ev-Ek-Sen (2009) Declaration on the Launch of Ev-Ek-Sen (Union of Homebased Workers) and Call For Unity. Available at: http://www.homeworkersww.org.uk/resources/declaration-on-the-launch-of-ev-eksen-union-of-homebased-workers (accesed 21.3.2016).

Fashion United (2016) Global Fashion Industry Statistics- International Apparel. Available at: https://fashionunited.com/global-fashion-industry-statistics (accessed 14.10.2016).

Fernandez-Stark K, Frederick S and Gereffi G. (2011) The Apparel Global Value Chain-Economic Upgrading and Workforce Development. Available at: http://www.cggc.duke.edu/pdfs/2011-11-11_CGGC_Apparel-Global-Value-

Chain.pdf (accessed 12.10.2016).

Hattatoglu D and Tate J (2016) Home-based Work and New Ways of Organizing in the Era of Globalization. In Lambert R and Herod A (eds.) Neoliberal Capitalism and Precarious Work: Ethnographies of Accommodation and Resistance. Cheltenham: Edward Elgar, pp. 96-124.

Heery E and Salmon J (2002) The Insecure Workforce. London and New York: Routledge. 
ITUC (2011) Living with Economic Insecurity: Women in Precarious Work. Available at: http://www.ituc-csi.org/IMG/pdf/Women_8_march_EN.pdf (accessed 4.8.2014).

Ilkkaracan I (2012) Why so Few Women in the Labour Market in Turkey?' Feminist Economics 18 (1): 1-37.

Jenkins J (2013) Organising 'Spaces of Hope': Union Formation by Indian Garment Workers. British Journal of Industrial Relations 51: 623-643.

Jenkins J (2015) The Significance of Grass-Roots Organising in the Garment and Electrical Value Chains of Southern India. In Newsome K, Taylor P, Bair J and Rainnie A (eds.) Putting the Labour in its Place-Labour Process Analysis and Global Value Chains. London: Palgrave, pp.195-213.

Jenkins J and Blyton P (2017) In debt to the Time-Bank: The Manipulation of Working Time in Indian Garment Factories and 'Working Dead Horse'. Work, Employment and Society 31(1): 90-105.

Jonas AEG (1996) Local Labour Control Regimes: Uneven Development and the Social Regulation of Production. Regional Studies 30 (4): 323-338.

Kalaycioglu S and Rittersberger H (1998) Is Iliskilerine Kadinca Bir Bakis: Ev Hizmetinde Calisan Kadinla' (A Female Perspective on Work Relations: Female Domestic Workers). In: Mirzaoglu AB (eds.) 75 Yilda Kadinlar ve Erkekler (Women and Men in 75 Years) Istanbul: Istanbul Tarih Vakfi, pp.225-235.

Kalleberg AL (2000) Nonstandard employment relations: Part-time, temporary and contract work. Annual review of sociology 26(1): 341-365.

Kandiyoti D (2012) Foreword. In Dedesoglu S Women Workers in Turkey-Global Industrial Production in Turkey, New York: I.B.Taurus.

Kidder T and Raworth K (2004) 'Good Jobs' and Hidden Costs: Women Workers Documenting the Price of Precarious Employment. Gender \& Development 12 (2): 12 21.

Munck R (2013) The Precariat: A View from the South. Third World Quarterly 34 (5): $747-762$.

Neilson B and Rossiter N (2008) Precarity as a Political Concept, or, Fordism as Exception. Theory, Culture \& Society 25 (7-8): 51-72. 
Newsome K, Taylor P, Bair J and Rainnie A (2015) Putting Labour in its Place-Labour Process Analysis and Global Value Chains. London: Palgrave.

Pattenden J (2016) Working at the Margins of Global Production Networks: Local Labour Control Regimes and Rural-Based Labourers in South India. Third World Quarterly 37(10): 1809-1833.

Rainnie A, Herod A and McGrath-Champ S (2011) Review and Positions; Global Production Networks and Labour. Competition and Change 15(2): 155-169.

Riisgard L and Hammer N (2011) Prospects for Labour in Global Value Chains: Labour Standards in the Cut Flower and Banana Industries. British Journal of Industrial Relations 49(1): 168-190.

Sarioglu E (2013) Gendering the Organization of Home-based Work in Turkey: Classical versus Familial Patriarchy. Gender, Work \& Organization 20 (5): 479-497.

Senses N (2015) Rethinking Migration in the Context of Precarity: The Case of Turkey. Critical Sociology 42(7-8): 975-987.

Shukaitis S (2013) Recomposing Precarity: Notes on the Laboured Politics of Class Composition. Ephemera 13 (3): 641-658.

Standing G (2011) The Precariat: The New Dangerous Class. London: Bloomsbury.

Tartanoglu S (2015) Beyond Informality: Effectiveness of a New Actor for Representing Call Centre Workers in Turkey. Industrial Relations Journal 46 (5-6): $381-397$.

Taylor P (2010) The Globalisation of Service Work; Analysing the Transcontinental Call Centre Value Chain. In Thompson P and Smith C (eds.) Working Life: Renewing Labour Process Analysis. Basingstoke: Palgrave Macmillan, pp. 244-268.

Thornley C, Jeffreys S and Appay B (2010) Globalization and Precarious Forms Production and Employment-Challenges for Workers and Unions. Cheltenham: Edward Elgar.

Toksoz G, Dedeoglu S, Memis Parmaksiz E and Kaya Bahce S (2014) Turkiye'de Kadin Isgucu Profili ve Istatistiklerinin Analizi. Ankara: T.C. Aile ve Sosyal Politikalar Bakanligi Kadinin Statusu Genel Mudurlugu. 
TURKSTAT (2016) Labour Force Statistics, Available at: http://www.turkstat.gov.tr/Start.do; jsessionid=2nmMY8qfFfL8cL18JX9NtvpZfhNyV TVQplGHp5xHSLmn8d5NJWkV!257067445 (accessed 13.09.206).

Vosko LF, MacDonald M and Campbell I (2009) Gender and the Contours of Precarious Employment. London and New York: Routledge.

World Integrated Trade Solution, (2015) Turkey Textiles and Clothing Exports by Country and Region. Available at: http://wits.worldbank.org/CountryProfile/en/Country/TUR/Year/2015/TradeFlow/Exp ort/Partner/all/Product/50-63_TextCloth (accessed 12.10.2016). 